\title{
Identifikasi Faktor-Faktor yang Mempengaruhi Pendapatan Petani Asparagus \\ (Kasus pada Kelompok Tani Sayur Mertanadi di Desa Pelaga, Kabupaten Badung)
}

\author{
K A EDI SUYOGA, DWI PUTRA DARMAWAN, \\ I NYOMAN GEDE USTRIYANA
}

\author{
Program Studi Agribisnis, Fakultas Pertanian, Universitas Udayana \\ J1. PB. Sudirman Denpasar 80323 \\ Email: kaedisuyoga@gmail.com \\ dwiputradarmawan@yahoo.com
}

\begin{abstract}
Identification of Factors Affecting Asparagus Farmer's Income (Case On Kelompok Tani Mertanadi at Pelaga Village, Badung Regency)
\end{abstract}

Asparagus is one of the horticultural products that has high sales value. Mertanadi Vegetables Farmer group is a group of farmers who produce asparagus in Bali. The purpose of this study was to determine the factors of production that have an impact on farmer's income. Data collection for this study was conducted from May to June 2016 with accidental sampling method. PLS path modeling is used to analyze the influence of production factors on income. Results showed some of the factors of production such as chicken manure, cow manure, NPK fertilizer, and urea fertilizer has effect on revenue. All factors of production are reflected through latent variables fertilizers and chemicals, with t-statistics value of 5.625 at $5 \%$ significance level and also with $\mathrm{f}^{2}$ value of 0.552 in the model. Other factors of production used as an indicator obtained did not have a significant effect on revenue. Suggestion can be given based on this research to farmers is to optimize the use of fertilizers and drugs in the production process by taking into account the costs required. Government is expected to support the farmers with price support policies. Further research is expected to do research with indicators relating to cost with more indicators and a larger sample.

Keywords: factors, production, asparagus, farmer's income

\section{Pendahuluan}

\subsection{Latar belakang}

Tanaman hortikultura merupakan salah satu tanaman yang menunjang pemenuhan gizi mayarakat sebagai sumber vitamin, mineral, protein, dan karbohidrat. Produk hortikultura terbesar adalah buah-buahan dan sayuran. Produksi buah-buahan utama di tahun 2004 mencapai 9,1 juta ton diikuti sayuran 3,6 juta ton, dan tanaman biofarmaka sebesar 92,6 ribu ton (Bappenas, 2004). Hortikultura 
merupakan komoditas pertanian khas tropis yang potensial untuk dikembangkan di Indonesia dan memiliki prospek yang cerah di masa mendatang sekaligus sebagai sumber perolehan devisa bagi Indonesia. Nilai ekspor hortikultura pada bulan Februari 2007 mengalami peningkatan sebesar 34,46 persen dari bulan Januari 2007 dan diperkirakan akan terus mengalami peningkatan seiring dengan peningkatan jumlah penduduk dan tingkat pendapatan (Departemen Pertanian, 2007).

Kebutuhan produk hortikultura yang terus meningkat tidak sebanding dengan pasokan komoditas hortikultura ke pasar-pasar tradisional hingga supermarket dan hypermarket di seluruh Indonesia sehingga belum mampu mencukupi kebutuhan konsumen. Kondisi tersebut menyebabkan banyak kelompok tani yang memfokuskan produksinya pada beberapa jenis tanaman hortikultura. Salah satu kelompok tani yang fokus pada budidaya hortikultura adalah kelompok tani sayur Mertanadi di Desa Pelaga. Adapun beberapa tanaman hortikultura yang dibudidayakan oleh kelompok tani Mertanadi diantaranya asparagus, brokoli, baby buncis, tomat cherry, selada, dan kailan.

Pembudidayaan komoditi asparagus menjadi fokus utama dari kelompok tani Mertanadi. Hal ini disebabkan harga asparagus jauh lebih tinggi dari komoditi lainnya dan cuaca di daerah Pelaga sangat mendukung pembudidayaan asparagus. Meskipun didukung kondisi cuaca, jumlah produksi asparagus kelompok Mertanadi tetap mengalami fluktuasi. Fluktuasi jumlah produksi asparagus disebabkan oleh beberapa faktor, seperti usia petani, jenjang pendidikan, lama berusahatani, luas area tanam, tenaga kerja, pupuk dan obat-obatan diantaranya pupuk kandang ayam, pupuk kandang sapi, pupuk urea, pupuk NPK, serta obat-obatan yang mencakup pestisida dan fungisida.

Faktor-faktor produksi usahatani sangat penting bagi petani untuk menjalankan usahataninya. Produktivitas optimum dapat dicapai apabila faktorfaktor produksi dialokasikan secara efektif dan efisien. Apabila petani mengalokasikan faktor produksi secara efektif dan efisien tentunya petani mampu mengalokasikan biaya usahatani secara tepat, guna mendapatkan keuntungan maksimum (Soekartawi, 2002).

Perlu dilakukan penelitian untuk mengidentifikasi faktor-faktor yang berpengaruh terhadap produktivitas asparagus dalam upaya meningkatkan pendapatan petani pada kelompok tani Mertanadi di Desa Pelaga Kabupaten Badung, guna membantu petani serta pihak lain yang terkait untuk mengetahui input produksi yang paling berpengaruh dalam meningkatkan pendapatan petani. diharapkan nantinya membantu petani dalam upaya mengoptimumkan penggunaan input produksi dalam proses budidaya karena hasil produksi dipengaruhi oleh faktor produksi itu sendiri.

\subsection{Tujuan Penelitian}

Berdasarkan permasalahan yang telah dikemukakan di atas, maka penelitian ini memiliki tujuan untuk mengetahui faktor (konstruk) yang secara dominan mempengaruhi pendapatan petani asparagus di kelompok tani Mertanadi. 


\section{Metodelogi Penelitian}

\subsection{Lokasi dan Waktu Penelitian}

Penelitian ini dilaksanakan di Desa Pelaga, Kecamatan Petang, Kabupaten Badung dari bulan Mei sampai dengan Juni 2016. Penentuan lokasi penelitian ditentukan dengan teknik purposive, yaitu penentuan daerah penelitian secara sengaja karena di Desa Pelaga terdapat kelompok tani yang berfokus memproduksi asparagus yakni Kelompok Tani Sayur Mertanadidan belum adanya penelitian terkait dilokasi ini.

\subsection{Populasi dan Sampel}

Populasi dalam penelitian ini yaitu petani yang terdaftar dan aktif dalam buku keanggotaan Kelompok Tani Mertanadisebanyak 60 petani. Jumlah sampel dalam penelitian ini sebanyak 38 orang yang ditentukan dengan menerapkan rumus slovin (Sevela, 1993).

$$
\mathrm{n}=\frac{\mathrm{N}}{1+\mathrm{Ne}^{2}}
$$

Keterangan:

$\mathrm{n} \quad=$ Jumlah sampel

$\mathrm{N}=$ Jumlah populasi

$\mathrm{e} \quad=$ Batas toleransi kesalahan $(10 \%)$

Sedangkan teknik pengambilan sampel mempergunakan metode accidental sampling yang berarti pengambilan sampel dari populasi dilakukan secara kebetulan (accidental) tanpa memperhatikan strata yang ada dalam populasi tersebut (Sugiyono, 2008).

\subsection{Jenis dan Sumber Data}

Jenis data yang digunakan dalam penelitian ini meliputi data kuantitatif dan kualitatif. Data kuantitatif meliputi data produksi asparagus kelompok dari laporan tahunan kelompok, data penggunaan dan harga faktor produksi, data produksi,data pembelian asparagusdi lokasi penelitian, data karakteristik petani yang meliputi umur, luas area tanam, lama pendidikan formal, pengalaman berusahatani, dan biaya penggunaan tenaga kerja. Data kualitatif meliputiprofillokasi penelitian.

Data yang digunakan dalam penelitian ini meliputi data primer yang terdiri atas data karakteristik petani, dan data penggunaan harga faktor produksi. Data sekunder, meliputi data hasil produksi asparagus dan data pembelian asparagus dari laporan tahunan Kelompok Tani Mertanadi, data profildan struktur organisasi di lokasi penelitian. 


\subsection{Metode Pengumpulan Data}

Metode pengumpulan data dalam penelitian ini sebagai berikut.

1. Library research, yaitu penelitian yang dilakukan dengan membaca berbagai sumber literatur atau kajian pustaka yang berkaitan dengan penelitian yang dilakukan.

2. Field research, ialah pengumpulan data yang diperoleh secara langsung dari lapangan. Adapun metodeyang diterapkan meliputipengamatan (observation), wawancara (interview), dan kuesioner (questionnaires).

\subsection{Metode Analisis Data}

Data dalam penelitian ini dijelaskan secara deskriptif kuantitatif, dianalisis menggunakan aplikasi komputer SmartPLS 2.0M3dengan rincian sebagai berikut.

\subsubsection{Evaluasi Model PLS}

Model Evaluasi PLS berdasarkan pada pengukuran prediksi yang mempunyai sifat no-parametrik. Pleh karena itu, model evaluasi PLS dilakukan dengan menilai outer model dan inner model.

1. Evaluasi outer model.

Terdapat uji validitas dan realibilitas pada evaluasi outer model. Uji validitas dilakukan untuk mengetahui bahwa pengukur-pengukur (indikator) dari suatu konstruk seharusnya berkolerasi tinggi danpengukur-pengukur (infdikator) konstruk yang berbeda seharusnya tidak berkolerasi dengan tinggi. Uji validitas indikator refleksif dapat dilihat dari nilai loading faktor untuk setiap konstruk, dimana nilai (1) loading faktor yang direkomendasikan antara 0.6 s.d. 0.7 untuk penelitian yang bersifat explanatory. (2) Nilai AVE harus lebih besar dari 0.5. Selain uji validitas, pengukuran model juga dilakukan untuk menguji akurasi, konsistensi ketetapan instrument dalam mengukur konstruk. Uji reliabilitas dilakukan dengan melihat nilai Composite Reliability dengan rentang nilai 0.6 s.d. 0.7.

2. Evaluasi inner model.

Dalam menilai model structural (inner model) PLS dapat dilihat dari nilai RSquares untuk setiap konstruk endogen sebagai kekuatan prediksi dari model structural. Nilai R-Squares 0.67; 0.33; dan 0.19 untuk konstruk dalam model structural menunjukkan model kuat, moderat, dan lemah (Chin, 1998 dalam Ghozali, 2012).

\section{Hasil dan Pembahasan}

\subsection{Deskriptif Indikator Pembentuk Konstruk}

Karakteristik petani asparagus di Desa Pelagasecara rinci dapat dilihat pada Tabel 1. berikut ini. 
Tabel 1.

Karakteristik Petani Kelompok Tani Sayur Mertanadi

\begin{tabular}{lcr}
\hline Uraian Karakteristik Petani & Rentang & Rata-rata \\
\hline Luas areatanam (Are) & 10 s.d. 60 & 25 \\
Usia petani (Tahun) & 25 s.d. 60 & 41 \\
Pengalaman berusahatani (Tahun) & 1 s.d. 6 & 3,5 \\
Jenjang pendidikan formal (Tahun) & 0 s.d. 12 & 9 \\
\hline
\end{tabular}

Sumber: Data primer (diolah), 2016.

Tabel 1 menunjukkan luas area tanam petani tergolong sempit karena ratarata luas lahan garapan yang kurang dari 0,5 hektar. Petani anggota Kelompok Tani Mertanadi ke dalam usia produktif karena rata-rata usia petani yang kurang dari 64 tahun dan hal ini menunjukkan petani dapat bekerja dengan baik dan maksimal. Rata-ratapengalaman petani berusahatani padi selama 3,5 tahun dan hal ini menunjukkan bahwa petani masih ada dalam tahap pembelajaran mengingat asparagus baru dibudiayakan selama 6 tahun di Desa Pelaga. Rata-rata lama pendidikan formal petani anggota Kelompok Tani Mertanadi selama 9 tahun dan hal ini menunjukkan bahwa petani lebih cepat dalam menerapkan teknologi baru serta menerima inovasi dari penyuluh pertanian karena pendidikan petani sudah melebihi anjuran pemerintah yaitu wajib belajar sembilan tahun.

Pupuk dan obat-obatan yang digunakan oleh petani dalam proses budidaya adalah sebagai berikut: pupuk kandang ayam, pupuk kandang sapi, pupuk NPK jenis PHONSKA, pupuk urea, Antracol, dan Amistar. Pupuk kandang yang digunakan biasanya dibeli oleh petani di luar bantuan koperasi sedangkan untuk pupuk NPK, urea, Antracol, dan Amistar disediakan oleh Koperasi Tani Mertanadi.

\subsection{Faktor yang Memiliki Pengaruh Dominan Terhadap Pendapatan Petani 3.2.1 Evaluasi outer model}

Rancangan model identifikasi faktor yang mempengaruhi pendapatan petani terdiri atas 3 konstruk yakni konstruk pendapatan petani yang terdiri dari indicator pendapatan petani pada bulan februari, maret, dan april; konstruk karakteristik petani yang terdiri dari indikator usia, luas area tanam, pengalaman berusahatani, dan jenjang pendidikan formal; serta konstruk pupuk dan obat-obatan yang terdiri atas indikator pupuk kandang ayam, pupuk kandang sapi, NPK, urea, dan obat-obatan. Konstruk pupuk dan obat-obatan dan kerakteristik petani kemudian dihubungkan dengan konstruk pendapatan petani, tetapi terdapat dua indikator yang tidak memenuhi persyaratan agar konstruk yang dibentuk menjadi valid dan reliabel yakni indikator usia dan obat-obatan, secara lebih jelas dapat dilihat pada Gambar 1. 


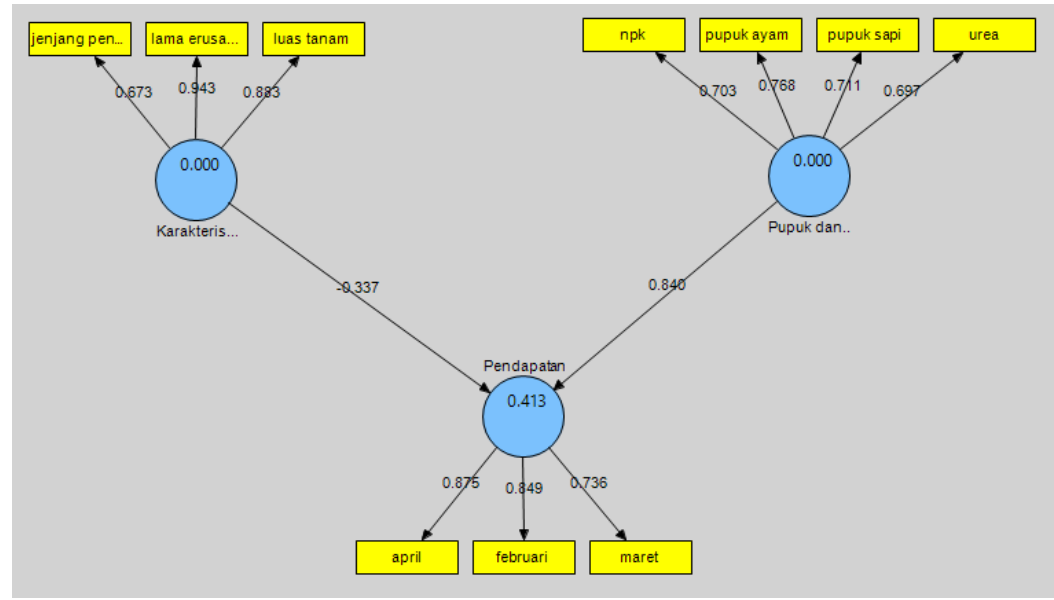

Gambar 1.

Diagram Path Hubungan Antar Konstruk

Indikator yang terdapat pada seluruh konstruk pada Gambar 1 adalah indikator yang memenuhi syarat validitas dimana nilai loading faktor yang dimiliki setiap indikator ke konstruknya lebih besar dari 0,6 untuk konstruk dengan indikator refleksif, nilai cross loading indikator terhadap konstruk lain kurang dari 0,7, dan nilai AVE lebih besar dari 0,5. Seluruh konstruk yang terbentuk juga didapatkan reliable dengan nilai Composite Reliability lebih besar dari 0,7 untuk semua konstruk yang terbentuk.

\subsubsection{Evaluasi Inner Model}

Dalam menilai inner model dalam PLS, dilihat melalui nilai $R$ Squares dan hasil bootstrapping. Secara keseluruhan hasil analisis inner model dapat dilihat pada Tabel 2.

Tabel 2.

Overview Output Analisis Pengaruh Variabel Konstruk Karakteristik Petani dan Pupuk dan Obat - Obatan Terhadap Pendapatan

\begin{tabular}{lllllll}
\hline Konstruk & AVE & $\begin{array}{l}\text { Composite } \\
\text { Reliability }\end{array}$ & R Square & $\begin{array}{l}\text { Cronbachs } \\
\text { Alpha }\end{array}$ & Communality & Redundancy \\
\hline $\begin{array}{l}\text { Karakteristik } \\
\text { Petani }\end{array}$ & 0,707174 & 0,876671 & & 0,797374 & 0,707174 & \\
$\begin{array}{l}\text { Pendapatan } \\
\text { Pupuk dan }\end{array}$ & 0,676052 & 0,861631 & 0,413208 & 0,758265 & 0,676052 & $-0,197718$ \\
Obat-obatan & & 0,811489 & & 0,705571 & 0,518729 & \\
\hline
\end{tabular}

Sumber: Data primer diolah, 2016

Seperti ditunjukkan pada Tabel 2 nilai R Square yang dimiliki oleh model adalah sebesar 0.413 dimana nilai ini memiliki arti bahwa model yang didapatkan untuk analisis ini tergolong moderat dan sebesar $41.3 \%$ variasi keragaman pendapatan petani dapat dijelaskan oleh konstruk karakteristik petani dan konstruk pupuk dan obat-obatan. Setiap konstruk juga harus memiliki nilai T Statistics sebesar 
1.96 dengan tingkat $\alpha=5 \%$ agar dapat dinyatakan memiliki pengaruh terhadap pendapatan petani. Ternyata konstruk karakteristik petani tidak memiliki pengaruh yang nyata terhadap pendapatan petani karena nilai T Statistics yang dimiliki kurang dari 1,96 seperti yang ditunjukkan pada Tabel 3 .

Tabel 3.

Path Coefficients (Mean, STDEV, T-Values)

\begin{tabular}{lccccc}
\hline Hubungan & $\begin{array}{c}\text { Original } \\
\text { Sample } \\
(\mathbf{O})\end{array}$ & $\begin{array}{c}\text { Sample } \\
\text { Mean } \\
(\mathbf{M})\end{array}$ & $\begin{array}{c}\text { Standard } \\
\text { Deviation } \\
(\text { STDEV) }\end{array}$ & $\begin{array}{c}\text { Standard } \\
\text { Error } \\
(\text { STERR) }\end{array}$ & $\begin{array}{c}\text { T Statistics } \\
(\mid \mathbf{O} / \text { STERR })\end{array}$ \\
\hline $\begin{array}{l}\text { Karalteristik } \\
\text { Petani }>\end{array}$ & $-0,337079$ & $-0,221290$ & 0,174528 & 0,174528 & 1,931375 \\
$\begin{array}{l}\text { Pendapatan } \\
\text { Pupuk dan } \\
\text { Obat-obatan - }\end{array}$ & 0,839858 & 0,820305 & 0,149285 & 0,149285 & 5,625860 \\
$>$ Pendapatan
\end{tabular}

Sumber: Data primer diolah, 2016

\section{Simpulan dan Saran}

Penelitian mengenai identifikasi faktor-faktor yang mempengaruhi pendapatan petani asparagus ini memiliki kesimpulan bahwa faktor penggunaan pupuk dan obat-obatan yang dicerminkan oleh indikator pupuk kandang ayam, pupuk kandang sapi, NPK, dan urea memiliki pengaruh nyata terhadap pendapatan petani. Saran yang dapat diberikan kepada petani adalah untuk menggunakan input pupuk dan obat-obatan dengan tetap memperhatikan jumlah biaya yang digunakan terkait penggunaan faktor produksi tersebut agar dapat menekan biaya yang dikeluarkan dan tetap mendapatkan pendapatan yang tinggi.

\section{Daftar Pustaka}

Antara, M. 2014. Format dan Substansi Proposal Penelitian Sosial Ekonomi. Program Studi Agribisnis Fakultas Pertanian Universitas Udayana. Denpasar.

Bollen K.A. 1989. Structural Equation with Laten Variabels. Departement of Sociology, John Wiley \& Sons, New York.

Chin, W. 1998. The Partial Least Square Approach for Structural Equation Modeling. Cleveland. Ohio.

Dita A. 2012. Faktor-faktor yang Mempengaruhi Tingkat Kesejahteraan Karyawan Outsourcing PT. Perkebunan Nusantara II Unit Kebun Sawit Seberang. Jurnal Ilmiah. Universitas Sumatra Utara. Tersedia: http:// download.portalgaruda.org /article. php? article $=58806 \& v a l=4143$. Diakses tanggal 7 Juli 2015.

Fakultas Pertanian Universitas Udayana. 2012. Pedoman Penyelesaian Tugas Akhir Program Sarjana. Fakultas Pertanian Universitas Udayana. Denpasar.

Fitriani. 2009. Budidaya Tanaman Kubis Bunga (Brassica Oleraceae Var Botrytis L.)Di Kebun Benih Hortikultura (Kbh)Tawangmangu. [Tugas Akhir On-line] DIII Agribisnis Hortikultura dan Arsitektur Pertamanan. Universitas Sebelas 
Maret. Tersedia: http://core.ac.uk/download/files/478/16507079.pdf. Diakses tanggal 15 Desember 2015.

Ghozali, Imam. 2011. AplikasiAnalisis Multivariate Dengan Program IBM SPSS 19 (edisi kelima). Universitas Diponegoro. Semarang.

Ghozali, dan Hengky. 2012. Partial Least Squares Konsep, Teknik dan Aplikasi SmartPLS 2.0M3 Untuk Penelitian Empiris. Badan Penerbit Universitas Diponegoro. Semarang.

Ghozali, I. 2011. Structural Equation Modeling, Edisi 3, Metode Alternatif dengan Partial Least Square. Badan Penerbit Universitas Diponegoro.

Hair et. al. 2006. Multivariate Data Analysis, Sixth Edition. New Jersey : Prentice Hall, Upper Saddle River.

Kelompok Tani Mertanadi. 2015. Laporan Tahunan Koperasi Mertanadi. Kelompok Tani Mertanadi. Badung.

Soekartawi, A. Soeharjo, J.L Dillon, J.b Hardaker. 1984. Ilmu Usaha Tani dan Penelitian Untuk Pengembangan Petani Kecil. Universitas Indonesia Press. Jakarta.

Sawana S. 2007. Analisis Faktor-faktor yang Mempengaruhi Produksi Jagung di Kabupaten Blora. Tesis Magister Ilmu Ekonomi dan Studi Pembangunan Universitas Diponegoro. Semarang. Tersedia: http: //eprints.undip.ac.id/ 18736/ 1/ Sawa_Suryana.pdf. Diakses tanggal 19 Juli 2015.

Sevela, G. C. 1993. Pengantar Metode Penelitian. Universitas Indonesia Press. Jakarta.

Tenaya, I M. N. 2009. Ekonometrika Program Studi Agribisnis. Laboratorium Statistika. Fakultas Pertanian Universitas Udayana.

Tenaya, I M. N. 2016. Structure Equation Modeling (PLS) (Kajian Kepustakaan). Laboratorium Multimedia dan Komputasi. Fakultas Pertanian Universitas Udayana. 